\title{
The therapeutic effects of Physalis alkekengi hydroalcoholic extract on estrogen receptor-positive breast cancer mice model: possible role of autophagy in this therapeutic response
}

\author{
Zahra Zare $^{\mathbb{1}}$, Maryam Teimouri ${ }^{* *}$ \\ ${ }^{1}$ Department of Biology, Farhangian University, Tehran, Iran. \\ ${ }^{2}$ Department of Biology, Roudehen Branch, Islamic Azad University, Roudehen, Iran.
}

*Corresponding Author: Maryam Teimouri, Department of Biology, Roudehen Branch, Islamic Azad University, Roudehen, Tehran, Iran, Fax: 02188200114, Email: teimourimaryam93@gmail.com

\begin{abstract}
Background and aims: Although some preclinical and clinical studies have extensively confirmed the pharmacological effects of the hydroalcoholic extract (HE) of Physalis alkekengi on several diseases, little is known about the effects of $P$. alkekengi HE (PAHE) on breast cancer. Therefore, this study aimed to investigate the therapeutic effect of PAHE on estrogen receptor+ breast cancer.

Methods: To this end, tumors were created in mice by injecting MC4L2 cells into the sternum of the mice. Then, the animals were gavaged for 16 days at 10, 50, and $100 \mathrm{mg} / \mathrm{kg}$ daily of PAHE. In addition, the tumor growth and body weight of the mice were measured on the $16^{\text {th }}$ day, and they were killed on $21^{\text {st }}$ day. Finally, their tumor tissues were removed and the apoptotic cell tissue and expression of the ATG-5 gene were studied as well. The experiments were repeated three times, and the data were analyzed using SPSS software $(P<0.001$ and $P<0.05)$.

Results: The average body weight of the control group significantly decreased 16 days after tumor establishment $(P<0.001)$. Further, the PAHE inhibited the growth of the breast cancer tumor in higher doses $(50 \& 100 \mathrm{mg} / \mathrm{kg}, P<0.001)$. Based on the results, a significant histopathological alteration was found in the breast tumors of the PAHE-treated groups compared with the control group, including the decreased level of mitotic cells the intensive level of necrotic cells and lymphocyte infiltration into the breast tumors bearing mice 21 days after PAHE administration $(P=0.012)$. Eventually, PAHE significantly increased the mRNA level of the expression of the autophagy ATG-5 specific gene in the effective dosage-treated group $(50 \mathrm{mg} / \mathrm{kg}, P=0.037)$.

Conclusion: The evidence suggests that the PAHE has a suitable efficacy for the treatment of ER+ breast cancer by promoting autophagy mechanisms into these tumor types.

Keywords: Physalis alkekengi, ER ${ }^{+}$breast cancer, BALB/c mice, Autophagy, mRNA level expression, ATG-5 gene
\end{abstract}

Received: 13 March 2020, Accepted: 13 June 2020, ePublished: 29 December 2020

\section{Introduction}

Breast cancer is one of the most common malignancies affecting women worldwide and the second leading cause of cancer mortality in females. In most cases, this neoplasm has an uncontrolled growth of mammary cells originating from the inner lining of milk ducts or the lobules as a consequence of mutations in the genes that are responsible for adjusting the cell development. Nevertheless, from the genetic and histopathological perspectives, the underlying mechanisms of breast cancer growth remain mainly unknown. Furthermore, the majority of them are estrogen-dependent diseases with augmenting morbidity and mortality rates (1-3).

Nowadays, procedures containing mastectomy, radiotherapy, chemotherapy, monoclonal antibodies, endocrine therapies, and herbal medicine have been introduced as therapeutic strategies for breast cancer. Nonetheless, no reliable and definitive cure has been established despite the notable scientific and technological improvement in its treatment and management. Therefore, in recent years of cancer research, the exploration of novel and efficient anticancer medications has permanently been a focal point (4-8).

Based on various hypotheses, promoting cellular death mechanisms on malignant tumor cells is a crucial target for increasing the effectiveness of cancer therapeutic approaches. In this case, autophagy cell death has a direct vital role in achieving this goal $(9,10)$. Nowadays, several anticancer autophagy mediator drugs have been successfully developed and trailed on several types of cancers. Phosphoinositide 3-kinase class III inhibitors including wortmannin/LY29002 and 3MA (11), 
along with vacuolar-type $\mathrm{H}^{+}$-ATPase inhibitors such as bafilomycin A1 and concanamycin A (12) can be considered as the brilliant samples of anticancer autophagy mediator drugs. Most autophagy mediators target and promote the cell death mechanism through activating the intracellular hydrolysis process that is related to lysosomes $(11,12)$.

Moreover, medicinal herbals have generally been utilized for various diseases (e.g., cancer) as organic and safe drugs although they may cause damage due to their undesirable side effects. Accordingly, studying the effects of different doses of these remedies would have an effective role in recognizing their safety profile (13-15). Recently, the aqueous extract of winter cherry fruits (Physalis alkekengi, family Solanaceae) has been utilized as an herbal medicine with antioxidant activity and therapeutic effects in Iranian traditional medicine. Additionally, modern medical features have revealed that $P$. alkekengi is valid on the immunity system, cancer, enzymes, and sexual and reproductive hormones $(16,17)$. Accordingly, the present study investigated the therapeutic effects of $P$. alkekengi hydroalcoholic extract (PAHE) on the mice models of estrogen receptor (ER)-positive breast cancer and then explored the autophagy mediating potential of this extract on the $\mathrm{ER}^{+}$class of breast tumors.

\section{Materials and Methods}

\section{Cell culture}

The cell line (MC4-L2) of the breast (adenocarcinoma, mouse) was obtained from the Iranian Biological Resource Center. In addition, DMEM/F-12 was used as the culture, along with the HEPES buffer (15 mM), l-glutamine, penicillin $(100 \mu \mathrm{g} / \mathrm{mL})$, streptomycin $(100 \mu \mathrm{g} / \mathrm{mL}), 10 \%$ fetal bovine serum (Gibco BRL, Life Technologies), and medroxyprogesterone acetate $(10 \mathrm{nM}$, Sigma Chemicals, Ontario, Canada). The cells were grown at $37^{\circ} \mathrm{C}$ in a humidified atmosphere with 5\% $\mathrm{CO}_{2}(18,19)$.

\section{Animals}

Twenty- eight inbred female BALB/c mice (6-8 weeks old) were purchased from the Pasteur Institute of Iran (Iran, Tehran) and were maintained at 12 hours of the lighting cycle, excellent and free nutrition, and enough water conditions. The study was performed according to the instructions given by the IACUC of Tehran University of Medical Sciences.

\section{Tumorigenicity}

MC4-L2 cells were trypsinized and re-suspended in the 10-fold excess culture medium. Finally, $1 \times 106$ prepared cells were injected into the animal right inguinal flank (19).

\section{Preparation of PAHE}

The protocol was performed according to Gharib's study
(20). Further, PAHE was obtained from local herbalists, identified as previously mentioned, and further confirmed by the Research Center of the Agriculture School of Shiraz University. The fruits were cleaned and washed with ionized water. Then, they were dried $\left(70^{\circ} \mathrm{C}\right)$, powdered, and extracted by the percolation method (21).

\section{Experimental animals}

Twenty-eight ER ${ }^{+}$breast cancer BALB/c mice models were divided into four different groups (7 mice in each group). The mice were treated with the PAHE for 16 days and then killed after 21 days. A part of the removed tumor tissue was used for histopathological tests, and part of it was used to perform molecular tests as follows:

I. Keeping the control group including untreated $\mathrm{ER}^{+}$ breast cancer animal models without any extract for 16 days;

II. Including untreated $\mathrm{ER}^{+}$breast cancer, animal models received $10 \mathrm{mg}$ of PAHE (per kg b.w. in $1 \mathrm{~mL}$ ) for 16 days;

III. Including untreated $\mathrm{ER}^{+}$breast cancer, animal models received $50 \mathrm{mg}$ of the PAHE (per $\mathrm{kg}$ b.w. in $1 \mathrm{~mL}$ ) for 16 days;

IV. Including untreated $\mathrm{ER}^{+}$breast cancer, animal models received $100 \mathrm{mg}$ of the PAHE (per kg b.w. in $1 \mathrm{~mL}$ ) for 16 days.

\section{Body weight and tumor size measurement}

Using a Vernier caliper (Mitutoyo, Japan), the animal weight and tumor volume were monitored continuously and weekly $(22,23)$.

- $\mathrm{V}=1 / 6 \pi \mathrm{LWD}$

- $\mathrm{L}=$ Length

- $\mathrm{W}=\mathrm{Width}$

- $\mathrm{D}=$ Depth.

\section{Hematoxylin and eosin ( $H$ \& $E$ ) staining}

To avoid the PAHE response, the mice were euthanized five days after the last extract administration and were finally euthanized using cervical dislocation. In addition, tumor tissues were fixed in formaldehyde (10\%) and then passaged and embedded in paraffin. Next, paraffin blocks were sectioned $(3 \mu \mathrm{m})$ and stained with HE. Eventually, sections were detected by a belayed histopathologist $(24,25)$.

\section{RNA extraction and the real-time polymerase chain reaction}

The quantitative expression of the ATG-5 gene was evaluated by the real-time polymerase chain reaction (RTPCR) method within specific primers $(25,26)$. To this end, the total RNA was extracted from the ER+ breast tumors of the mice using a TRIzol ${ }^{\oplus}$ reagent (Life Technologies) kit according to the manufacturer's instructions, and then the DNaseI digestion (Thermo Fisher Scientific, Waltham, MA, 
USA) treatment was performed to remove any probably contaminating DNA. Furthermore, the concentration and quality of the extracted RNA were assayed by the UV absorbance at 260 and $280 \mathrm{~nm}$ (A260/280 ratio) and investigated by vertical electrophoresis. Next, cDNA from the extracted RNAs was synthesized by administering the Prime Script ${ }^{\mathrm{TM}}$ RT reagent kit (Fermentas, Germany). Finally, the RT-PCR was performed in triplicate using the SYBR $^{\circ}$ Premix Ex Taq ${ }^{\text {TM }}$ II (Takara) in 40 cycles at $95^{\circ} \mathrm{C}$ for 30 seconds, followed by 40 cycles at $95^{\circ} \mathrm{C}$ and $60^{\circ} \mathrm{C}$ for 5 and 30 seconds, respectively. The relative expressions of the ATG-5 gene were calculated using the comparative cycle threshold $\left(2^{-\Delta \Delta C T}\right)$ method with glyceraldehyde 3 -phosphate dehydrogenase (GAPDH) as the endogenous control (the housekeeping gene) in order to check the data. The sequences of the primers for ATG-5 and GAPDH genes are indicated in Table 1.

\section{Statistical analysis}

The obtained data were analyzed by Tukey and KruskalWallis tests using SPSS software (version 22), and $P$ values less than 0.001 and 0.05 were considered statistically significant (27).

\section{Results}

Animal weight

Figure 1 displays the weight changes of animals that were treated with the PAHE. The results vigorously confirmed the beneficial effects of PAHE on animal weight. In this regard, no significant changes in mice weight were observed in the PAHE groups. In contrast, the average weight of the control group significantly reduced $(P<0.001) 16$ days after study initiation.

\section{Analysis of tumor size}

The effects of the PAHE on the tumor progression and development of the animals are depicted in Figure 2. In the treatment groups, the tumor size among different doses of PAHE close to $0.6 \mathrm{~mm}$ was in the greatest dimension with the dosage of $10 \mathrm{mg} / \mathrm{kg}$ after 16 days. The smallest detectable size of the malignant lesion was close to $0.3 \mathrm{~mm}$ in diameter for the dosage of $50 \mathrm{mg} / \mathrm{kg}$. Furthermore, the histologic size of the untreated mice in the control group was larger than $0.7 \mathrm{~mm}$. Therefore, the average tumor size was significantly less in the drug receiving group compared

Table 1. The sequence of ATG-5 and GAPDH primers

\begin{tabular}{ll}
\hline Primers & Sequence \\
\hline ATG 5-F & 5'- TTTGCATCACCTCTGCTTTC-3' \\
ATG 5-R & 5'- TAGGCCAAAGGTTTCAGCTT-3' \\
GAPDH-F & 5 - GAA GGT GAA GGT CGG AGT CA-3 \\
GAPDH-R & 5 -TTG AGG TCA ATG AAG GGG TC-3 \\
\hline
\end{tabular}

Note. ATG-5: Autophagy-related gene-5; GAPDH: Glyceraldehyde

3-phosphate dehydrogenase.

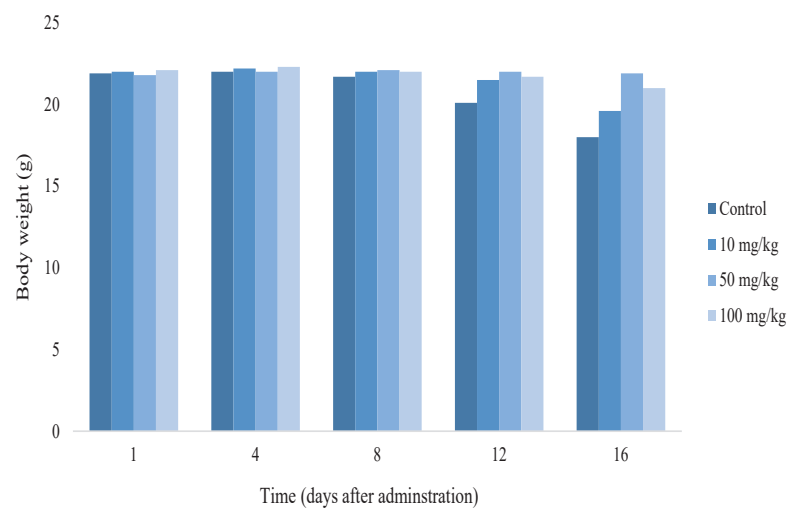

Figure 1. PAHE effects on body weight (g) in the animal model of $E R+$ breast cancer.

Note. PAHE: Physalis alkekengi hydroalcoholic extract; ER: Estrogen receptor. The weight of all animals was measured every four days after starting extract administration. According to the data, no sensible losing weight was observed in all dosage-treated (i.e., 10, 50, and $100 \mathrm{mg} / \mathrm{kg}$ ) groups. However, the average body weight of the control group significantly decreased 16 days after tumor establishment. The reported data are $(P<0.001)$ significant compared to the control group.

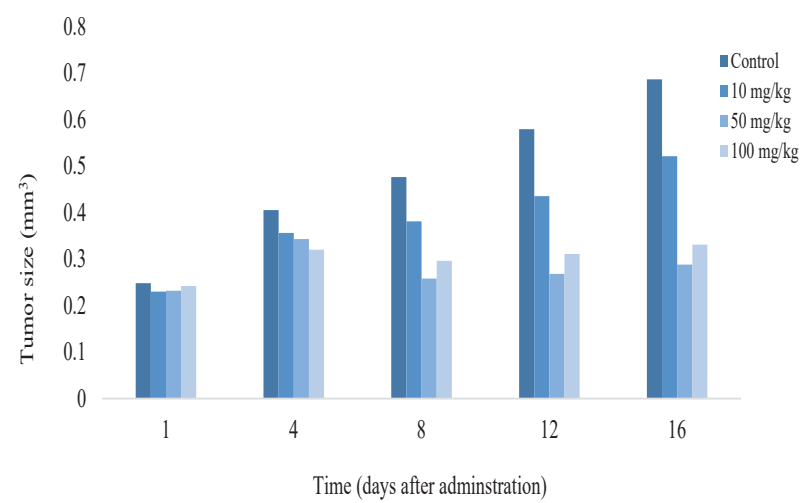

Figure 2. PAHE effects on the tumor size $\left(\mathrm{mm}^{3}\right)$ in the animal model of $\mathrm{ER}^{+}$breast cancer

Note. PAHE: Physalis alkekengi hydroalcoholic extract; ER: Estrogen receptor. PAHE (i.e., 10, 50, and $100 \mathrm{mg} / \mathrm{kg}$ ) was given after tumor establishment until day 16 . The control group was studied using any administration. The tumor volume was measured every four days by a digital vernier caliper and using $V=1 / 6(\pi \mathrm{LWD})$ where $\mathrm{L}=$ length, $\mathrm{W}=$ width, and $\mathrm{D}=$ depth. According to the observation, the average tumor volume was significantly less than that of the control group eighth, twelve, and sixteen days after PAHE administration to groups treated with 50 and $100 \mathrm{mg} / \mathrm{kg}$ doses. The reported data are compared to the control group $(P<0.001)$.

to the control group. Based on the results, statistically significant differences were found between the compared groups with regard to the tumor size $(P<0.001)$.

\section{Histopathological index}

The highest diagnostic accuracy of the histopathological lesions of the tumor (Figure 3) was achieved using an independent pathologist for each subject, which is listed in Table 2. Histopathologically, breast tumors in the control group were compared with those in the groups treated with PAHE after 21 days. Based on the findings, neoplastic cells 
Table 2. Macroscopic and histological indices in the breast cancer tissue following treatment by hematoxylin and eosin staining by Kruskal-Wallis analysis

\begin{tabular}{|c|c|c|c|c|c|c|}
\hline \multirow{2}{*}{ Indices } & \multicolumn{4}{|c|}{ Dose Rank } & \multirow{2}{*}{$P$ value } & \multirow{2}{*}{ IQR } \\
\hline & $\mathbf{0}$ & 10 & 50 & 100 & & \\
\hline Hyperchromatic nucleus & 11.00 & 6.50 & 6.50 & 2.00 & 0.01173 & 1.5 \\
\hline Mitotic figures & 11 & 8 & 3.5 & 3.5 & 0.01173 & 1.75 \\
\hline Hyperemia and bleeding & 2 & 5 & 9.5 & 9.5 & 0.01174 & 1.75 \\
\hline Pleomorphism of tumor cells & 11 & 8 & 5 & 2 & 0.01173 & 2.5 \\
\hline Apoptotic cells & 2 & 6.5 & 6.5 & 11 & 0.01172 & 1 \\
\hline Necrotic cells & 2 & 6.5 & 6.5 & 11 & 0.01172 & 2.25 \\
\hline
\end{tabular}

Note. IQR: Interquartile range. A statistically significant difference was observed based on the results between different doses of the extract $(P=0.012)$.

within tissue lesions in these tumors often had increased mitotic rates (were frequently in mitosis), greater nuclear pleomorphism or abundant polygonal, and/or highly pleiomorphic cells, prominent nucleoli, hyperchromatic nuclei, and loss of tubular morphology.

Additionally, cells were significantly arranged with necrosis and hemorrhage or the congestion patterns of variable degrees in some cases and ranged from multinucleated giant cells with higher lymphocytes, plasma cells (lymphoplasmacytic infiltration), and rare neutrophils (the accumulations of mixed inflammatory cells) in some areas. Generally, histopathological alterations in the breasts were higher at doses of 50 and $100 \mathrm{mg} / \mathrm{kg}$ (Table 2).

\section{Analysis of gene expression by RT-PCR}

Figure 4 displays the relative expression of the ATG-5 gene of mice breast tumors. Based on the assessments, a significant up-regulation was observed (a 1.82-fold change) in the ATG-5 gene, as one of the central autophagy genes, in the $\mathrm{ER}^{+}$breast tumor tissues of mice following treatment with the PAHE compared to the control group $(P=0.037)$.

\section{Discussion}

Nowadays, cancer treatment is considered a serious challenge for everyone worldwide. Although multiple hypotheses have been proposed for its association, there is no explicit concept in this respect. Accordingly, the present study compared the performance of histopathology investigation in evaluating breast cancer lesions on various dosages of $P$. alkekengi. The result demonstrated the potential and important role of the histopathology technique in the types of groups undergoing the treatment effect of $P$. alkekengi and confirmed that the diagnostic performance between the four groups $(10,50$, and 100 $\mathrm{mg} / \mathrm{kg}$ and control) was significantly different. To the best of our knowledge, no study has so far evaluated the effects of PAHE on breast tumors in mice. Nonetheless, recent studies have focused on the alternative species of the family Solanaceae and shown that the dichloromethane extract of Physalis pubescens L. has the properties of cancerprevention due to the extracted natural compounds from
P. pubescens L. that possess anticancer activities $(28,29)$. Moreover, most medicinal herbals have antioxidant activities due to phenolic compounds with anticancer properties (30). In the present study, $P$. alkekengi as an anticancer compound could elevate the levels of the ATG5 gene expression with significant differences $(P<0.001)$
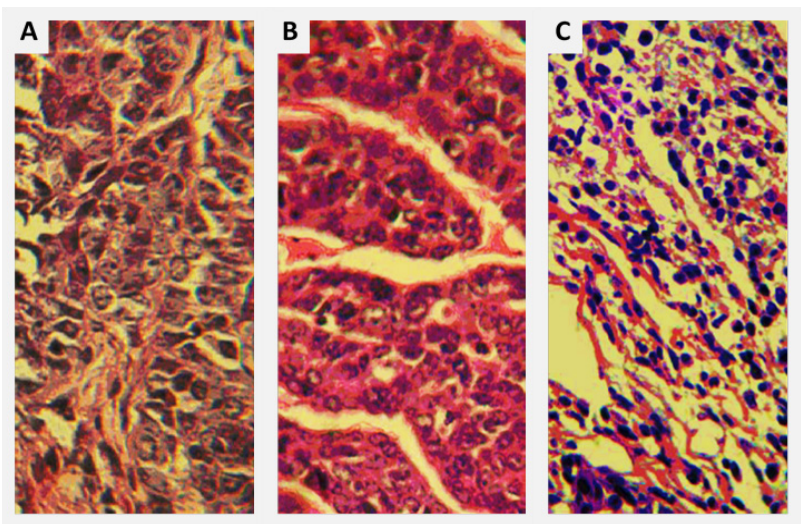

Figure 3. Breast tumor hematoxylin and eosin staining $(\times 400)$. Note. PAHE: Physalis alkekengi hydroalcoholic extract. (A) Breast tumor in the high clear mitotic body in the control group; (B) and (C) Decreased level of mitotic cells the intensive level of necrotic cells and lymphocytes infiltration into the breast tumors bearing mice 21 days after PAHE treatment ( 50 \& $100 \mathrm{mg} / \mathrm{kg}$ ) administration, respectively.

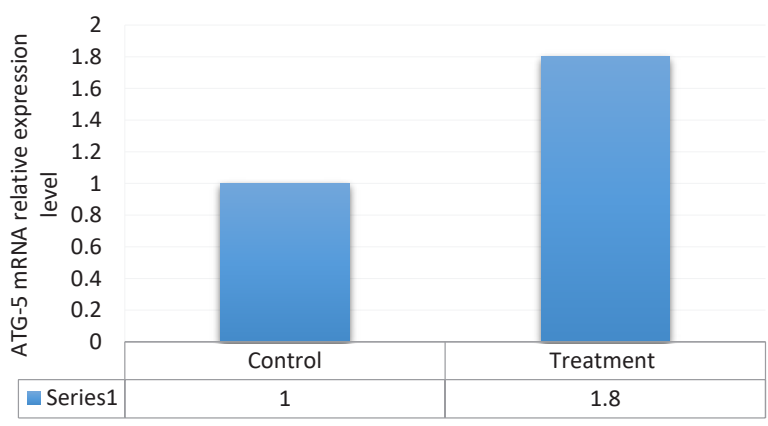

Figure 4. PAHE effects on the expression of autophagy ATG-5 gene expression in the animal model of $\mathrm{ER}^{+}$breast cancer.

Note. PAHE: Physalis alkekengi hydroalcoholic extract; RTPCR: Real-time polymerase chain reaction; ATG-5: Autophagyrelated gene-5; ER: Estrogen receptor. The control group was studied with any administration while the treatment group was treated with the more effective dosage of PAHE $(50 \mathrm{mg} / \mathrm{kg})$ for 16 days. The relative ATG-5 mRNA expression was directly measured based on breast tumors using the RT-PCR assay after 21 days $(P=0.037)$. 
in the most effective dosage of the PAHE $(50 \mathrm{mg} / \mathrm{kg}$ ) when compared to the control group (Figure 4). Based on this result, the current study could prove the potential of the PAHE for promoting autophagy mechanisms into the malignant $\mathrm{ER}^{+}$breast tumor cells.

On the other hand, the findings demonstrated that PAHE concentrations ranging from 50 to $100 \mathrm{mg} / \mathrm{kg}$ remarkably inhibited the proliferation of cancer cells with infiltrating inflammatory cells, tumor cell necrosis, and the like in a dose-dependent manner. These histopathologic observations were made during drug administration in high-doses toward low dosages. Therefore, our data indicated a potential role for $P$. alkekengi in breast carcinoma prevention. Similarly, Ding et al (28) reported the antitumor activity of $P$. pubescens $\mathrm{L}$. in the prostate cancer cells of microscopic images, which is consistent with the effect of $P$. pubescens $\mathrm{L}$ on tumor cells. Further, numerous studies (31-36) evaluated the therapeutic effects of $P$. alkekengi, due to its antioxidant properties or activity, on different diseases such as cancer, heart problems, diabetes, and infection. Furthermore, Torabzadeh et al suggested that the effect of the aqueous extract of $P$. alkekengi on the cancer cytotoxicity of the U937 cell line was convenient (37). In another study, Li et al (38) revealed the anticancer cytotoxic activity of this plant on tumor cells with cell lines such as HeLa and hepatoma. Moreover, other studies confirmed the effects of SMMC-7721 and HL-60 cell lines on various cancers (39-41) and reported that the administration of $P$. Alkekengi extracts remarkably reduced the tumoral level, which may contribute to a decline in the size of the prostate.

\section{Conclusion}

Briefly, our data showed that the effects of the PAHE were attributed to its natural compounds of the damage of the tumor tissue. In addition, the findings of this study may provide evidence for the potential application of $P$. alkekengi in the treatment of breast carcinoma and thus could help cure cancer by targeting some mine cellular death cascades including the autophagy mechanism. Therefore, further research is warranted to identify these anticancer ingredients of $P$. alkekengi with overdose and validate its utilization in animal studies.

Conflict of Interests

The authors declare no conflict of interests.

\section{Ethical Approval}

This study was subjected to the ethical rules of the Ministry of Health and conducted by considering ethical issues and obtaining a license from the ethics committee of the local institutes (IR.IAU. PS.REC.1397.350).

Authors Contribution

MT: Designing the study and conducting all testes and data collection; ZZ: Participating in data collection and analysis; MT and ZZ: Contributing to writing and editing the manuscript and approving the final version of the manuscript.

Funding/Support

The present study was supported by the "Pishgaman Institute for Gene Transfer" affiliated with Shahid Beheshti University (Thesis Number: 3527, 2018-2019).

References

1. Zarbaf R, Koushki Jahromi M, Sofiabadi M, Daryanoosh F, Peymani A. The effects of aerobic exercise in Sprague Dawley pregnant rats on BRCA1 and P53 gene expression of adult offspring breast tissue. Journal of Shahrekord University of Medical Sciences. 2018;20(5):13-24. [Persian].

2. Khaghani-Razi-Abad S, Hashemi M, Pooladi M, Entezari M, Kazemi E. Proteomics analysis of human oligodendroglioma proteome. Gene. 2015;569(1):77-82. doi: 10.1016/j. gene.2015.05.039.

3. Feng Y, Spezia M, Huang S, Yuan C, Zeng Z, Zhang L, et al. Breast cancer development and progression: risk factors, cancer stem cells, signaling pathways, genomics, and molecular pathogenesis. Genes Dis. 2018;5(2):77-106. doi: 10.1016/j.gendis.2018.05.001.

4. Tharmapalan P, Mahendralingam M, Berman HK, Khokha R. Mammary stem cells and progenitors: targeting the roots of breast cancer for prevention. EMBO J. 2019;38(14):e100852. doi: 10.15252/embj.2018100852.

5. Nagoor Meeran MF, Goyal SN, Suchal K, Sharma C, Patil CR, Ojha SK. Pharmacological properties, molecular mechanisms, and pharmaceutical development of asiatic acid: a pentacyclic triterpenoid of therapeutic promise. Front Pharmacol. 2018;9:892. doi: 10.3389/fphar.2018.00892.

6. Abdelmegeed SM, Mohammed S. Canine mammary tumors as a model for human disease. Oncol Lett. 2018;15(6):8195-205. doi: 10.3892/ol.2018.8411.

7. Sun YS, Zhao Z, Yang ZN, Xu F, Lu HJ, Zhu ZY, et al. Risk factors and preventions of breast cancer. Int J Biol Sci. 2017;13(11):1387-97. doi: 10.7150/ijbs.21635.

8. Jung KW, Won YJ, Kong HJ, Lee ES. Cancer statistics in Korea: incidence, mortality, survival, and prevalence in 2016. Cancer Res Treat. 2019;51(2):417-30. doi: 10.4143/crt.2019.138.

9. Lahart IM, Metsios GS, Nevill AM, Carmichael AR. Physical activity for women with breast cancer after adjuvant therapy. Cochrane Database Syst Rev. 2018;1(1):CD011292. doi: 10.1002/14651858.CD011292.pub2.

10. Dower CM, Wills CA, Frisch SM, Wang HG. Mechanisms and context underlying the role of autophagy in cancer metastasis. Autophagy. 2018;14(7):1110-28. doi: 10.1080/15548627.2018.1450020.

11. Powley IR, Patel M, Miles G, Pringle H, Howells L, Thomas A, et al. Patient-derived explants (PDEs) as a powerful preclinical platform for anti-cancer drug and biomarker discovery. $\mathrm{Br}$ J Cancer. 2020;122(6):735-44. doi: 10.1038/s41416-0190672-6.

12. Cotter K, Liberman R, Sun-Wada G, Wada Y, Sgroi D, Naber $\mathrm{S}$, et al. The a3 isoform of subunit a of the vacuolar ATPase localizes to the plasma membrane of invasive breast tumor cells and is overexpressed in human breast cancer. Oncotarget. 2016;7(29):46142-57. doi: 10.18632/oncotarget.10063.

13. Hoshyar R, Mohaghegh Z, Torabi N, Abolghasemi A. Antitumor activity of aqueous extract of Ziziphus jujube fruit in breast cancer: an in vitro and in vivo study. Asian Pac J Reprod. 2015;4(2):116-22. doi: 10.1016/S2305-0500(15)30007-5.

14. Megersa M, Jima TT, Goro KK. The use of medicinal plants for the treatment of toothache in Ethiopia. Evid Based Complement Alternat Med. 2019;2019:2645174. doi: 


\section{$10.1155 / 2019 / 2645174$}

15. Sung JE, Choi JY, Kim JE, Lee HA, Yun WB, Park JJ, et al. Hepatotoxicity and nephrotoxicity of saponin-enriched extract of Asparagus cochinchinensis in ICR mice. Lab Anim Res. 2017;33(2):57-67. doi: 10.5625/lar.2017.33.2.57.

16. Keshtkaran R, Vessal M. Effect of the hydroalcoholic extract of winter cherry fruits (Physalis alkekengi) on serum lipid profile and paraoxonase activity of healthy male rats. Zahedan J Res Med Sci. 2017;19(5):e9024. doi: 10.5812/zjrms.9024.

17. Gharib Naseri MK, Mohammadian M, Gharib Naseri Z. Antispasmodic effect of Physalis alkekengi fruit extract on rat uterus. Iran J Reprod Med. 2008;6(4):193-8.

18. Isanejad A, Alizadeh AM, Amani Shalamzari S, Khodayari H, Khodayari S, Khori V, et al. MicroRNA-206, let-7a and microRNA-21 pathways involved in the anti-angiogenesis effects of the interval exercise training and hormone therapy in breast cancer. Life Sci. 2016;151:30-40. doi: 10.1016/j. Ifs.2016.02.090.

19. Khori V, Amani Shalamzari S, Isanejad A, Alizadeh AM, Alizadeh S, Khodayari $S$, et al. Effects of exercise training together with tamoxifen in reducing mammary tumor burden in mice: possible underlying pathway of miR-21. Eur J Pharmacol. 2015;765:179-87. doi: 10.1016/j.ejphar.2015.08.031.

20. Gharib Naseri MK, Handali S, Hosseini H. Antispasmodic activity of Physalis alkekengi L. leaf hydroalcoholic extract on rat ileum. Iranian Journal of Medicinal and Aromatic Plants Research. 2007;23(3):340-9.

21. Alizadeh AM, Sadeghizadeh M, Najafi F, Ardestani SK, ErfaniMoghadam V, Khaniki M, et al. Encapsulation of curcumin in diblock copolymer micelles for cancer therapy. Biomed Res Int. 2015;2015:824746. doi: 10.1155/2015/824746.

22. Farhanji B, Latifpour M, Alizadeh AM, Khodayari H, Khodayari S, Khaniki M, et al. Tumor suppression effects of myoepithelial cells on mice breast cancer. Eur J Pharmacol. 2015;765:171-8. doi: 10.1016/j.ejphar.2015.08.023.

23. Mohsenikia M, Alizadeh AM, Khodayari S, Khodayari $H$, Kouhpayeh SA, Karimi A, et al. The protective and therapeutic effects of alpha-solanine on mice breast cancer. EurJ Pharmacol. 2013;718(1-3):1-9. doi: 10.1016/j.ejphar.2013.09.015.

24. Shiri S, Alizadeh AM, Baradaran B, Farhanghi B, Shanehbandi D, Khodayari S, et al. Dendrosomal curcumin suppresses metastatic breast cancer in mice by changing $\mathrm{m} 1 / \mathrm{m} 2$ macrophage balance in the tumor microenvironment. Asian Pac J Cancer Prev. 2015;16(9):3917-22. doi: 10.7314/ apjcp.2015.16.9.3917.

25. Kavosi A, Hosseini Ghale Noei S, Madani S, Khalighfard S, Khodayari $\mathrm{S}$, Khodayari $\mathrm{H}$, et al. The toxicity and therapeutic effects of single-and multi-wall carbon nanotubes on mice breast cancer. Sci Rep. 2018;8(1):8375. doi: 10.1038/s41598018-26790-x.

26. Akar U, Chaves-Reyez A, Barria M, Tari A, Sanguino A, Kondo $\mathrm{Y}$, et al. Silencing of $\mathrm{Bcl}-2$ expression by small interfering RNA induces autophagic cell death in MCF-7 breast cancer cells. Autophagy. 2008;4(5):669-79. doi: 10.4161/auto.6083.

27. Pourkamalzadeh M, Abtahi Froushani SM. In-vitro apoptotic effects of deferoxamine on the glioblastoma cell line. Iran South Med J. 2019;22(5):264-77. doi: 10.29252/ ismj.22.5.264. [Persian].

28. Ding W, Hu Z, Zhang Z, Ma Q, Tang H, Ma Z. Physapubescin
B exhibits potent activity against human prostate cancer in vitro and in vivo. J Agric Food Chem. 2015;63(43):9504-12. doi: 10.1021/acs.jafc.5b03045.

29. Zeng W, Wang Q, Chen L, Huang L, Zhao X. Anticancer effect of PP31J isolated from Physalis pubescens L. in human cervical carcinoma cells. Am J Transl Res. 2017;9(5):2466-72.

30. Asadi-Samani M, Kooti W, Aslani E, Shirzad H. A systematic review of Iran's medicinal plants with anticancer effects. J Evid Based Complementary Altern Med. 2016;21(2):143-53. doi: 10.1177/2156587215600873.

31. Poudel A, Gachumi G, Wasan KM, Dallal Bashi Z, ElAneed A, Badea I. Development and characterization of liposomal formulations containing phytosterols extracted from canola oil deodorizer distillate along with tocopherols as food additives. Pharmaceutics. 2019;11(4). doi: 10.3390/ pharmaceutics11040185.

32. Kamkar A, Shamse Ardekani MR, Shariatifar N, Misagi A, Mozaffari Nejad AS, Jamshidi AH. Antioxidative effect of Iranian Pulicaria gnaphalodes L. extracts in soybean oil. S Afr J Bot. 2013;85:39-43. doi: 10.1016/j.sajb.2012.12.001.

33. Rabiei Z, Rafieian-Kopaei M. Neuroprotective effect of pretreatment with Lavandula officinalis ethanolic extract on blood-brain barrier permeability in a rat stroke model. Asian Pac J Trop Med. 2014;7S1:S421-6. doi: 10.1016/s19957645(14)60269-8.

34. Rahimian GA, Rabiei Z, Tahmasebi B, Rafieian-Kopaei M, Ganji F, Rahimian R, et al. Comparing the combined effect of garlic and mint extract with metronidazole in Helicobacter pylori treatment. Iran J Pharm Sci. 2013;9(3):63-70.

35. Rahnama S, Rabiei Z, Alibabaei Z, Mokhtari S, Rafieian-Kopaei M, Deris F. Anti-amnesic activity of Citrus aurantium flowers extract against scopolamine-induced memory impairments in rats. Neurol Sci. 2015;36(4):553-60. doi: 10.1007/s10072014-1991-2.

36. Ghezelbash M, Masoudian N, Pooladi M. Beta actin expression profile in malignant human glioma tumors. Int Clin Neurosci J. 2018;5(2):72-7. doi: 10.15171/icnj.2018.14.

37. Torabzadeh P, Dezfulian M. Study of cytotoxicity effects of aqueous extract of Physalis alkekengi against U937 cell line. J Anim Physiol Dev. 2013;6(4):15-25.

38. Li X, Zhao J, Yang M, Liu Y, Li Z, Li R, et al. Physalins and withanolides from the fruits of Physalis alkekengi L. var. franchetii (Mast.) Makino and the inhibitory activities against human tumor cells. Phytochem Lett. 2014;10:95-100. doi: 10.1016/j.phytol.2014.08.004.

39. Beiraghdar F, Einollahi B, Ghadyani A, PanahiY, Hadjiakhoondi A, Vazirian M, et al. A two-week, double-blind, placebocontrolled trial of Viola odorata, Echium amoenum and Physalis alkekengi mixture in symptomatic benign prostate hyperplasia (BPH) men. Pharm Biol. 2017;55(1):1800-5. doi: 10.1080/13880209.2017.1328445.

40. Shams Lahijani M, Sanchooli N, Estakhr J, Hashemi SH. Effects of alcoholic extraxt of Physalis alkegni on the reproductive system,spermatogenesis and sex hormones on adult NMRI mice. Pharmacologyonline. 2008;3:110-8.

41. Nicholson TM, Ricke WA. Androgens and estrogens in benign prostatic hyperplasia: past, present and future. Differentiation. 2011;82(4-5):184-99. doi: 10.1016/j.diff.2011.04.006. 